Леонід Олійник, кандидат педагогічних наук, старший науковий співробітник Національний університет оборони України імені ІванаЧерняховського, м. Київ ORCID ID 0000-0002-7375-1281

DOI: $10.33099 / 2617-1775 / 2020-02 / 204-214$

\title{
ТЕОРЕТИКО-МЕТОДИЧНІ ЗАСАДИ НАВЧАННЯ ВІЙСЬКОВО- СПЕЦІАЛЬНИХ ДИСЦИПЛІН МАГІСТРІВ ВІЙСЬКОВО-СОЦІАЛЬНОГО УПРАВЛІННЯ:ЕКСПЕРИМЕНТАЛЬНЕ ДОСЛІДЖДЕННЯ
}

У статті розглянуто етапи організації $i$ проведення педагогічного експерименту та результати розвитку військово-спеціальної компетентності магістрів військово-соціального управлінняна основі використання структурно-функціональної технологї, щзо входить до складу методичної системи навчання військово-спеціальних дисииплін.

Розглянуто експериментальне дослідження та розкрито илях констатувального та формувального експерименту. Узагальнено результати експериментального дослідження розвитку військово-спеціальної компетентності у прочесі навчання слухачів з військовоспеціальних дисциплін у ВВНЗ. Доведено достовірність отриманих результатів за допомогоюметодівматематичної статистики.

Ключові слова: експеримент; навчання; військово-спеціальні дисципліни; магістри військово-соціального управління; методична система; технологія; військово-спеціальна компетентність.

Постановка проблеми. У педагогічній науці сьогодні триває пошук нових ефективних шляхів удосконалення освітнього процесу в умовах університетської освіти. Метою сучасної вищої військової школи повинні стати забезпечення становлення цілісної особистості, цілеспрямований вияв і розвиток ії здібностей, формування умінь і бажання навчатися протягом усього життя, створення умов для навчання як основи багатоступеневої військової освіти. Навчання - один із найдавніших видів людської діяльності, однак протягом усієї історії сутність цього процесу залишається незмінною, виявляючись у взаємодії викладача й слухача. Досягнення поставленої мети в процесі навчання, формування всебічно розвиненої особистості безпосередньо залежать від управління цим процесом. Визначений процес проходить шляхом розвитку військово-спеціальної компетентності майбутнього магістра військово-соціального управління (ВСУ), ефективність якого залежить від використання сучасної концепції навчання військово-спеціальних дисциплін магістрів ВСУ в умовах університетської освіти.

Аналіз досліджень і публікацій.Результати аналізу наукових праць 3 проблеми дослідження вказують на те, що окремі аспекти розробки теорії та вдосконалення методики навчання військовослужбовців розглядалися під різними кутами зору і були предметом уваги широкого кола науковців.

Концептуальні, змістовні й технологічні аспекти навчання військовоспеціальних дисциплін військовослужбовців у сучасних умовах розкрито у працях відомих педагогів:Д. Іщенка [6], М. Козяра [8], А. Лігоцького [10], М. Нещадима [12], В. Ягупова [15]. 
Не зважаючи на те, що стратегія реалізації навчання військово-спеціальних дисциплін як складової навчання магістрів взагалі та магістрів ВСУ зокрема видається очевидною, проте завершених версій свого втілення у системних дослідженнях вона не знайшла.

В основу побудови методичної системи навчання магістрів ВСУ покладені ідеї відомих вітчизняних дослідників: А. Автушенка [1], В. Баранівського [2], О. Бойка [3], А. Вітченка [4], А. Зельницького [5], С. Литвиновського [9], Т. Мацевка [11], В. Стасюка [13], О. Торічного [14]та ін. Завдяки цим дослідженням розроблено цілі, структуру і зміст навчання військово-спеціальних дисциплін магістрів, удосконалено форми, методи навчання магістрів, підготовлено навчальні плани і програми. Однак ці дослідження обмежувалися окремими компонентами навчання військово-спеціальних дисциплін магістрів. В них не повною мірою віддзеркалювалася зміна змісту навчання, яка викликана новими досягненнями у навчанні військово-спеціальних дисциплін, що потребує переосмислення цілей і завдань, змісту, форм, методів і засобів проведення морально-психологічного забезпечення діяльності військ та психологопедагогічної підготовки магістрів.

Метою статті $€$ експериментальне підтвердження ефективності цілеспрямованого розвитку військово-спеціальної компетентності магістрів ВСУза умов впровадження в освітній процес вищого військового навчального закладу (ВВНЗ) технології, що входить до складу методичної системи навчання військово-спеціальних дисциплін.

Виклад основного матеріалу. Серед пріоритетних завдань навчання військовоспеціальних дисциплін майбутніх магістрів ВСУ є завдання розвитку у них військовоспеціальної компетентності. Адже навчання і виховання особового складу підрозділів - їх прямий функціональний обов'язок. Такого висновку ми дійшли за результатами проведеного контент-аналізу службових обов'язків магістрів військово-соціального управління, серед яких визначено, що 80 \% посадових обов'язків стосуються сфери управління персоналом, національно-патріотичної підготовки, формування моральнопсихологічного стану особового складу, вивчення морально-ділових, професійних якостей підлеглих тощо.

На основі аналізу теоретичних підходів визначаємо військово-спеціальну компетентність магістра ВСУ як здатність використовувати професійний потенціал (систему знань, умінь, навичок 3 морально-психологічного забезпечення діяльності військ) для створення особистісної технології професійної діяльності в напрямі формування достатнього для виконання завдань за призначенням морально-психологічного стану особового складу та самовдосконалення та самореалізацію в процесі навчально-виховної діяльності.

Із метою перевірки рівня розвиненості військово-спеціальної компетентності магістрів військово-соціального управління нами було розроблено програму організації експериментального дослідження. Вона містила констатувальний $\mathrm{i}$ формувальний експерименти, які були проведені на базі Національного університету оборони України імені Івана Черняховського, Національної академії Державної прикордонної служби України імені Богдана Хмельницького, 
Національної академії Національної гвардії України, протягом 2016-2019 рр. Констатувальний експеримент передбачав такі етапи: визначення чистоти експерименту; визначення сучасного стану навчання військово-спеціальних дисциплін магістрів ВСУ; розробку гіпотези дослідження.

Військово-спеціальна компетентність магістра ВСУ передбачає мотиваційноціннісний, когнітивний, операційно-діяльнісний та особистісний компоненти.

Метою формувального експерименту була перевірка ефективності розробленої технології,що входить до складу методичної системи навчання військово-спеціальних дисциплінмагістрів ВСУ. Формувальний експеримент охоплював одну експериментальну (114 слухачів) і одну контрольну (108 слухачів) групи. У контрольній групі процес навчання майбутніх магістрів ВСУ відбувався за традиційною технологією навчання військово-спеціальних дисципліни, а в експериментальній групі - за розробленою технологією подання змісту навчання військово-спеціальних дисципліни.

Порівняльний аналіз динаміки розвиненості військово-спеціальної компетентності магістрів ВСУ відповідно до компонентів, отриманої в експериментальній (ЕГ) і контрольній (КГ) групах, на початку формувального експерименту та по його завершенні подано на рис. 1-4.

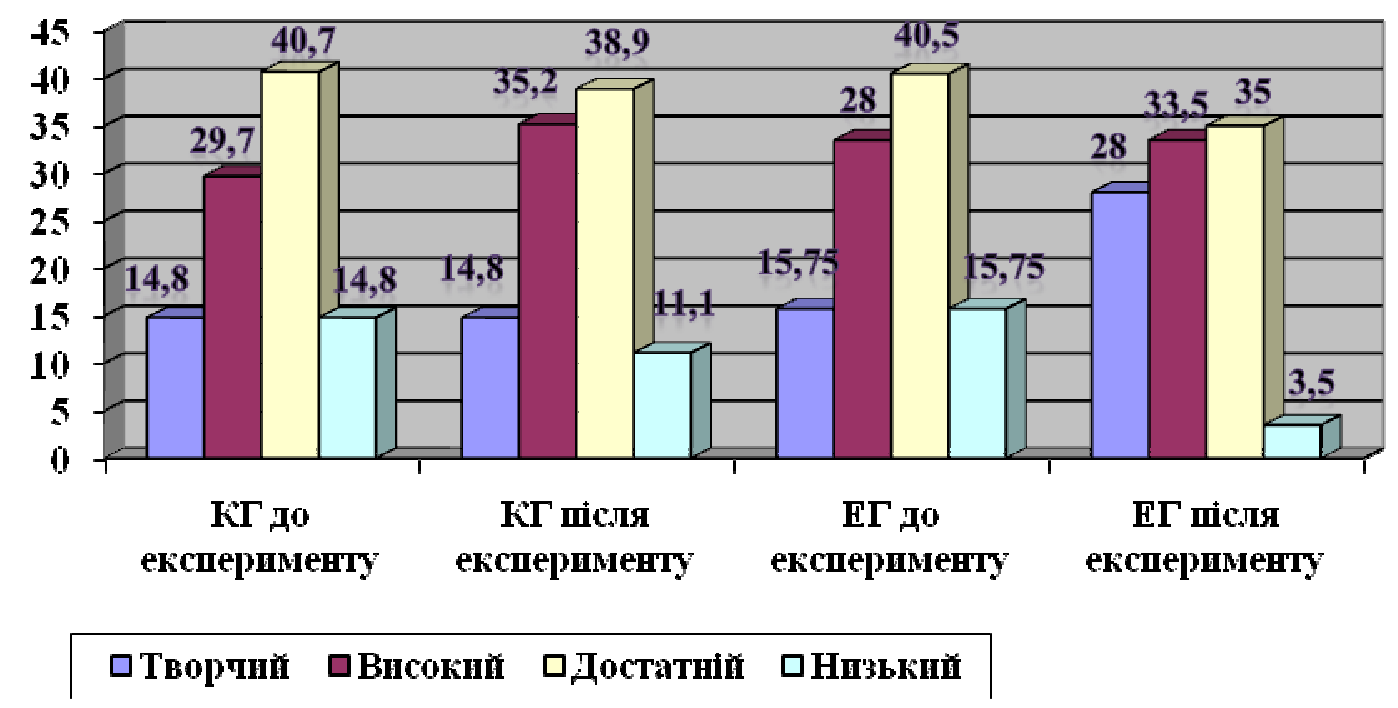

Рис. 1. Динаміка рівнів розвиненості військово-спеціальної компетентності магістрів ВСУ мотиваційно-ціннісного компоненту у контрольній та експериментальній групах на початку та наприкінці експерименту (у \%)

Розроблена педагогічна технологія спрямована на розвиток військовоспеціальної компетентності магістрів ВСУ, враховує основні принципи, форми, методи i засоби навчання та особливості змісту військово-спеціальних дисциплін. Її реалізація передбачає: застосування в освітньому процесі ВВНЗ компетентнісного підходу як основи формування професійно-важливих якостей у магістрів ВСУ; систематизацію компонентів, критеріїв та оцінних показників розвиненості військово-спеціальної компетентності магістрів ВСУ; інтегрованість технології розвитку військово-спеціальної компетентності магістрів ВСУ у цілісний освітній процес ВВНЗ щодо підготовки професіонала у 
сфері оборони; виведення міжпредметних зв'язків військово-спеціальних дисциплін на якісно новий рівень узгодження і координації складників освітньопрофесійних програм, де системоутворювальним чинником має виступати розвиток військово-спеціальної компетентності магістра ВСУ; використання у процесі навчання активних методів розвитку військово-спеціальної компетентності магістрів ВСУ.

Аналіз отриманих результатів розвиненості військово-спеціальної компетентностімотиваційно-ціннісного компонентупоказав що:творчого рівня $(\geq 0,92)$ досягли $28 \%$ слухачівЕГ, “ $\Delta$ ” по відношенню до результатів КГ становить $+13,2 \%$; високого рівня $\left(0,76 \leq K \sum \leq 0,92\right)$ досягли $33,5 \%$ слухачів, " $\Delta$ " -3 $\%$;достатнього рівня $\left(0,6 \leq K \sum \leq 0,75\right)$ досягли $35 \%$ слухачівЕГ, “ $\Delta$ " становить $3,9 \%$;низького рівня $\left(0,5 \leq K \sum \leq 0,59\right)$ досягли $3,5 \%$ слухачівЕГ, “ $\Delta$ ” становить $7,6 \%$.

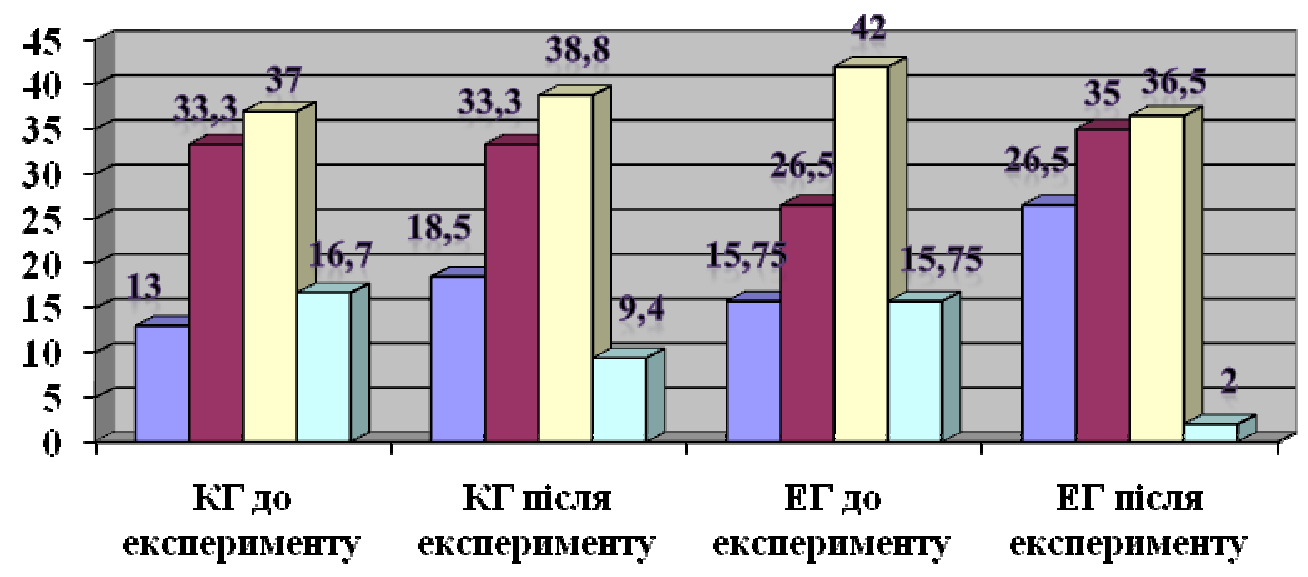

\section{口Твортий 口Високий 口Достатній 口Ннзький}

Рис. 2. Динаміка рівнів розвиненості військово-спеціальної компетентності магістрів ВСУ когнітивного компоненту у контрольній та експериментальній групах на початку та наприкінці експерименту (у \%)

Аналіз результатів розвиненості військово-спеціальної компетентності когнітивного компоненту показав, що творчого рівня $(\geq 0,92)$ досягли $26,5 \%$ слухачів ЕГ, “ $\Delta$ ” по відношенню до результатів КГ становить $+8 \%$;високого рівня $\left(0,76 \leq K \sum \leq 0,92\right)$ досягли $35 \%$ слухачів, " $\Delta$ " $+1,7 \%$;достатнього рівня $\left(0,6 \leq K \sum \leq 0,75\right)$ досягли $36,5 \%$ слухачів ЕГ, “ $\Delta$ ” становить $-2,3 \%$;низького рівня $\left(0,5 \leq \mathrm{K} \sum \leq 0,59\right)$ досягли $2 \%$ слухачів ЕГ, “ $\Delta$ ” становить $-7,4 \%$. 


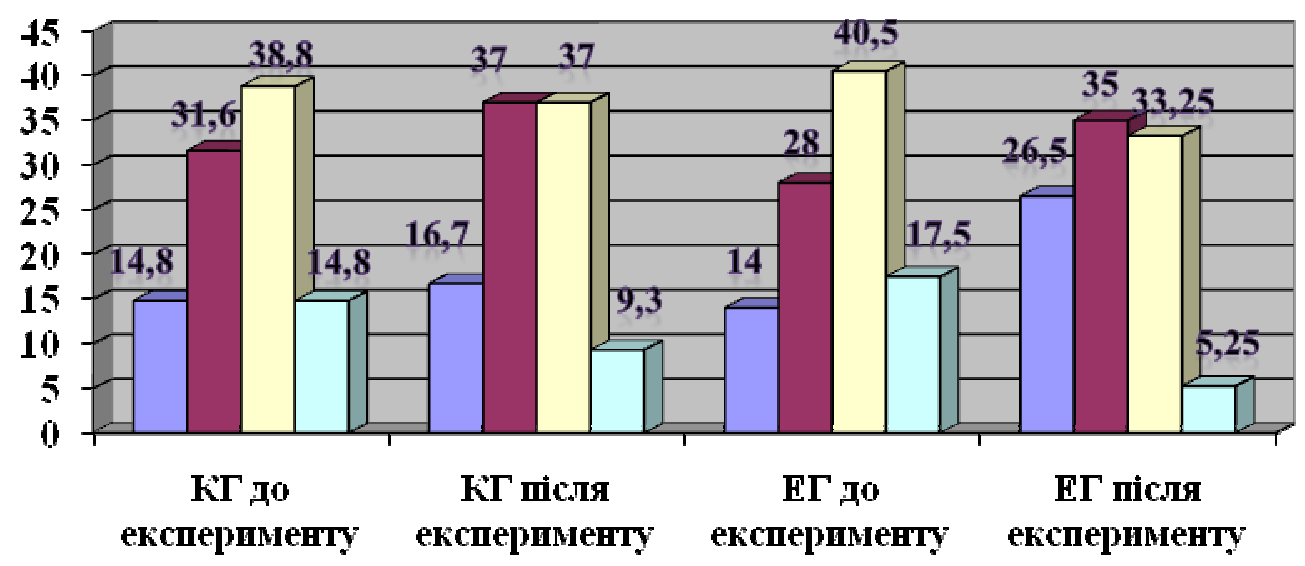

\section{口Твортий 口Високий 口Достатній 口Низький}

Рис. 3. Динаміка рівнів розвиненості військово-спеціальної компетентності магістрів ВСУ операційно-діяльнісного компоненту у контрольній та експериментальній групах на початку та наприкінці експерименту (у \%)

Аналіз результатів розвиненості військово-спеціальної компетентності операційно-діяльнісного компонента показав, що творчого рівня $(\geq 0,92)$ досягли $26,5 \%$ слухачів ЕГ, “ $\Delta$ ” по відношенню до результатів КГ становить $+9,8 \%$; високого рівня $\left(0,76 \leq \mathrm{K} \sum \leq 0,92\right)$ досягли $35 \%$ слухачів, " $\Delta$ " $2 \%$;достатнього рівня $\left(0,6 \leq K \sum \leq 0,75\right)$ досягли $33,25 \%$ слухачів ЕГ, “ $\Delta$ ” становить $3,75 \%$;низького рівня $\left(0,5 \leq K \sum \leq 0,59\right)$ досягли $5,25 \%$ слухачів ЕГ, “ $\Delta$ ” становить $4,05 \%$.

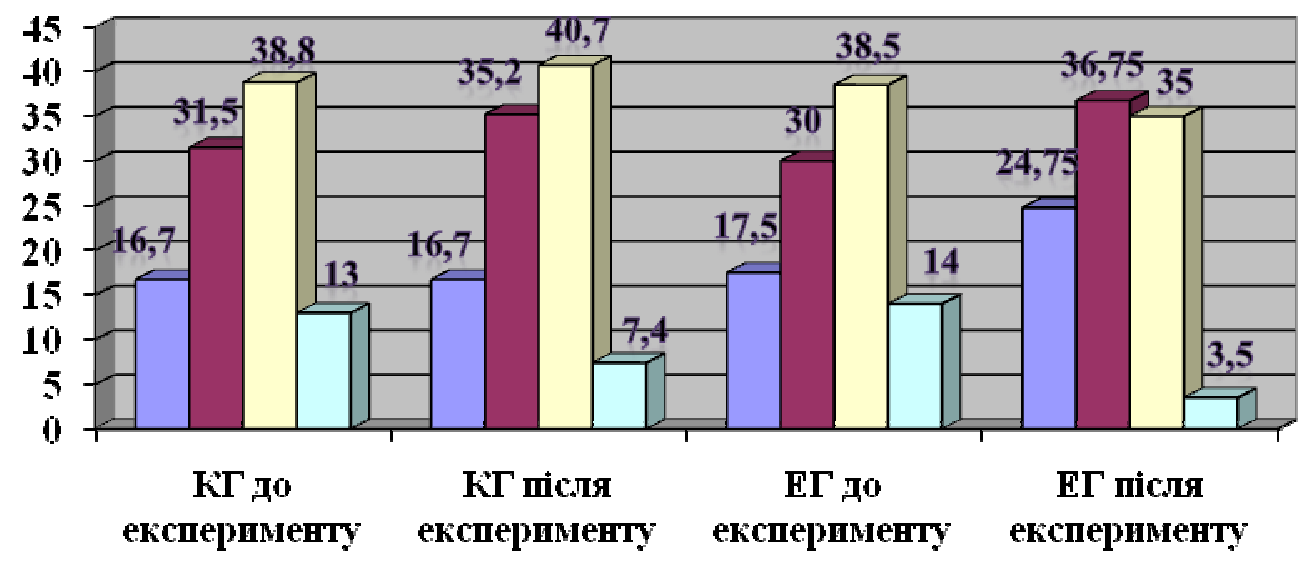

\section{口Твортий 口Високий 口Достатній 口Низький}

Рис. 4. Динаміка рівнів розвиненості військово-спеціальної компетентності магістрів ВСУ особистісного компоненту у контрольній та експериментальній групах на початку та наприкінці експерименту (у \%)

Аналіз результатів розвиненості військово-спеціальної компетентності особистісного компоненту показав, що творчого рівня $(\geq 0,92)$ досягли $24,75 \%$ слухачів ЕГ, “ $\Delta$ ” по відношенню до результатів КГ становить $+8,05$ \%; високого рівня $(0,76 \leq K \leq \leq 0,92)$ досягли $36,75 \%$ слухачів, “ $\Delta$ ” $+1,55 \%$;достатнього рівня 
$\left(0,6 \leq K \sum \leq 0,75\right)$ досягли $35 \%$ слухачів ЕГ, “ $\Delta$ ” становить $-5,7 \%$;низького рівня $\left(0,5 \leq K \sum \leq 0,59\right)$ досягли $3,5 \%$ слухачів ЕГ, “ $\Delta$ ” становить $-3,9 \%$.

Отримані дані свідчать про те, що до початку експерименту рівень розвиненості військово-спеціальної компетентності у магістрів ВСУ експериментальної та контрольної груп був практично однаковим.

Як бачимо, рівень розвиненості компонентів військово-спеціальної компетентності магістрів ВСУ в експериментальній групі після застосування розробленої технології підвищився.

Порівняльний аналіз результатів, отриманих в експериментальній i контрольній групах на початку формувального експерименту та по його завершенні, подано на рис. 5.

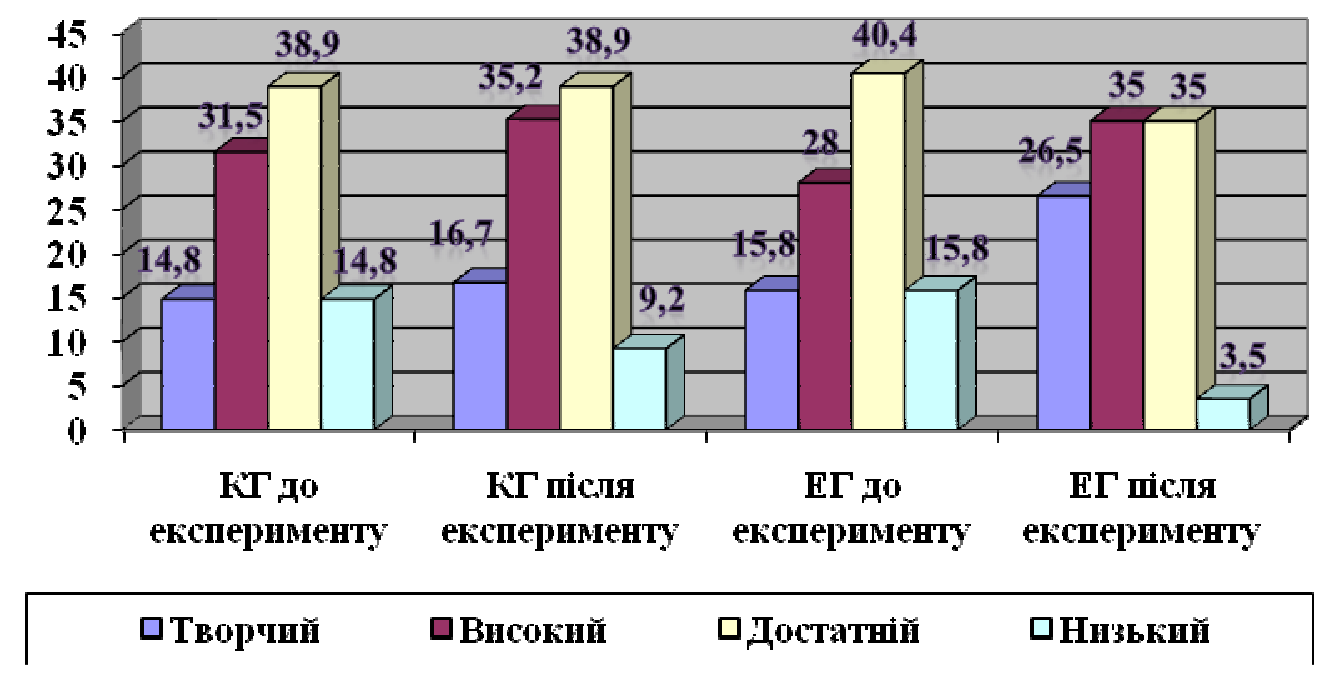

Рис. 5. Динаміка рівнів розвиненості військово-спеціальної компетентності магістрів ВСУ у контрольній та експериментальній групах на початку та наприкінці експерименту (у \%)

Результати порівняльного етапу в ЕГ та КГ дозволяють зробити висновок щодо переваг показників ефективності технології розвитку військово-спеціальної компетентності у слухачів ЕГ. Так, творчий і високий рівень розвиненості військово-спеціальної компетентності в ЕГ зріс з 43,8 \% до 61,5\% (на 17,7 \%), кількість слухачів з низьким рівнем зменшилася 3 15,8 \% до 3,5 \% (на 12,3\%). У КГ творчий та високий рівень розвиненості військово-спеціальної компетентності збільшився з 46,3 \% до 51,9 \% (на 5,6 \%), а кількість слухачів достатнього рівня залишилась без змін. Отримано позитивну динаміку рівнів розвиненості військово-спеціальної компетентності магістрів ВСУ, що свідчить про ефективність запропонованої нами технології.

Розв'язання завдання оцінювання ефективності технології розвитку військово-спеціальної компетентності магістрів ВСУ можна подати у вигляді такого алгоритму:

1. Обчислення середнього значення суми балів для кожної групи: $y_{1}=76$, $y_{2}=70$. Ефективність технології оцінювалася за сумарною кількістю балів експертної оцінки рівня розвиненості військово-спеціальної компетентності магістрів ВСУ. Ефективність технології розвитку військово-спеціальної 
компетентності магістрів ВСУ оцінювалась за сумарною кількістю балів, що отримані слухачами, зокрема, і групою у цілому за результатами експертної оцінки продуктивності діяльності при виконанні ними військово-спеціальних завдань за всіма показниками.

2. Визначення загального середнього значення для двох груп за формулою (1):

$$
\bar{y}=\frac{n\left(\overline{y_{1}}+\overline{y_{2}}\right)}{2 n}=73 \text {, }
$$

де $n$ - обсяг кожної вибірки, 2 - кількість технологій розвитку військовоспеціальної компетентності в процесі функціонування методичної системи навчання військово-спеціальних дисциплін, за якими ведеться навчання.

3. Визначення факторної та залишкової дисперсій. Наведено його узагальнені дані як суму результатів кожного слухача КГ та ЕГ.

$$
\delta_{\text {зал }}^{-2}=\sum_{i} \sum_{j}\left(y_{i j}-\bar{y}_{i}\right)^{2}=26614
$$

Сформулюємо гіпотези. Н0 - зростання рівнів розвиненості військовоспеціальної компетентності слухачів ЕГ на основі застосування у освітньому процесі ефективної технології розвитку військово-спеціальної компетентності є випадковим. Н1 - зростання рівнів розвиненості військово-спеціальної компетентності слухачів ЕГ на основі застосування в освітньому процесі ефективної технології розвитку військово-спеціальної компетентності $є$ суттєвим.

Факторна дисперсія обраховується за формулою (3):

$$
\delta_{\text {фак }}^{-2}=\sum_{i}^{2} n_{i}\left(\bar{y}_{i}-\bar{y}\right)^{2}=114(76-73)^{2}+108(70-73)^{2}=1998
$$

де $\mathrm{n}_{\mathrm{i}}-$ численність $i$-ї групи.

Залишкова дисперсія обраховується як:

$$
\delta_{\text {зал }}=\sum_{i} \sum_{j}\left(y_{i j}-\bar{y}_{i}\right)^{2}=26614
$$

Підраховуємо значення емпіричного статистичного критерію:

$$
\mathrm{F}_{\text {емп }}=\longrightarrow \frac{\delta_{\text {зал }}^{-2} 26614}{=}=13,32 ;
$$

$\delta_{\text {фак. }}^{-2} 1998$

Fкрит визначаємо за рівнем значимості $\alpha=0,05$, числом ступенів свободи чисельника $\mathrm{t}-1=1$ та числом ступенів свободи знаменника $\mathrm{n}-2=220$.

За таблицею - критерію [7] ( $\mathrm{F}$ - значення $\mathrm{p}=5$ \%) знаходимо:

$$
\mathrm{F}_{\text {крит }}(0,05 ; 1 ; 220)=9,6 . \mathrm{F}_{\text {емп }}=13,32>\mathrm{F}_{\text {крит }}=9,6 \text {. }
$$

Отже, Н0 відхиляється, приймається Н1, зростання рівнів військовоспеціальної компетентності слухачів на основі застосування у освітньому процесі ефективної технології розвитку військово-спеціальної компетентності є суттєвим $(\mathrm{p} \leq 0,05)$.

Висновки та перспективи подальших досліджень. Таким чином, результати експериментального дослідження свідчать, що реалізація застосованої технології в освітньому процесі ВВНЗ сприяє підвищенню рівня розвиненості військово- 
спеціальної компетентності у магістрів ВСУ. Дослідно-експериментальна робота підтверджує висунуту нами гіпотезу дослідження про те, що професійна діяльність магістрів ВСУ набуває більшої ефективності за умови цілеспрямованого розвитку в них військово-спеціальної компетентності на засадах компетентнісного підходу і впровадження в освітній процес ВВН3 розробленої технології.

У подальшому пропонується розробка перспективної системи магістрів ВСУ за стандартами НАТО.

\section{ЛІТЕРАТУРА}

1. Автушенко О. С. Система підготовки організаторів виховної роботи 3 військовослужбовцями в умовах університетської освіти: Автореф. дис... канд. пед. наук: 13.00.04 / О. С. Автушенко; Ін-т вищ. освіти АПН України. - К., 2003. - 20 с.

2. Баранівський В.Ф. Професійна компетентність фахівців 3 виховної та соціальнопсихологічної роботи для Збройних Сил України / В. Ф. Баранівський // Вісник Національного університету оборони України. - 2012. - Вип. 5 (30). - С. 5-10.

3. Бойко О. В. Формування готовності до управлінської діяльності у майбутніх магістрів військово-соціального управління: дис. … канд. пед. наук: 13.00 .04 / Бойко Олег Володимирович. - К., 2005. -476 с.

4. Вітченко А. О. Сучасні підходи до технологізації вищої освіти / А. О. Вітченко // Збірник наукових праць: Військова освіта - Вип. 1 (27). - 2013. - С. 48-58.

5. Зельницький А. М. Нові підходи до підготовки офіцерських кадрів - фахівців виховної роботи - як фактор запобігання конфліктів у військовому середовищі / А. М. Зельницький // Конфлікти в суспільстві : діагностика і профілактика: тези Третьої Міжнародної науковопрактичної конференції. - Київ - Чернівці, 1995. - С. 3-8.

6. Іщенко Д. В. Основи військової педагогіки / Д. В. Іщенко, А. Ф. Філіпов. Хмельницький : Вид-во Національної академії ПВУ, 2002. - 106 с.

7. Кыверялг А. А. Методыисследования в профессиональной педагогике / Кыверялг А. А. - Таллин: Валгус, 1980. - 336 с.

8. Козяр М. М. Теоретичні та методичні засади професійної підготовки особового складу підрозділів з надзвичайних ситуацій : автореф. дис. на здобуття наук. ступеня доктора пед. наук : 13.00.04 "Теорія та методика професійної освіти” / М. М. Козяр. - К., 2005. - 37 с.

9. Литвиновський $€$. Ю. Формування в офіцерів структури виховної роботи Збройних Сил України вмінь проектування виховного процесу :дис. ... канд. пед. наук: 13.00 .04 / Литвиновський Євгеній Юрійович. - К, 2003. - 208 с.

10. Лігоцький А. О. Теоретичні основи проектування сучасних освітніх систем / Анатолій Олексійович Лігоцький. - К. : Техніка, 1997. - 210 с.

11. Мацевко Т. М. Управлінська компетентність офіцерів військово-соціального управління / Т. М. Мацевко Вісник Національного університету оборони України. - 2015. Вип. 1(44). - С. 148-153.

12. Нещадим М. І. Військова освіта України: історія, теорія, методологія, практика : монографія / Микола Іванович Нещадим. - К. : Видавничо-поліграфічний центр “Київський університет", 2003. - $852 \mathrm{c}$.

13. Стасюк В. В. Особливості підготовки майбутніх магістрів військово-соціального управління до вимог Болонського процесу / В. В. Стасюк, Л. В. Олійник // Збірник наукових праць : військова освіта - Вип. 2 (28). - 2013. - С. 155-164.

14. Торічний О. В. Теорія і практика формування військово-спеціальної компетентності майбутніх офіцерів-прикордонників у процесі навчання : монографія / О. В. Торічний. Хмельницький : Вид-во Нац. академії Держ. прикордон. служби України ім. Б. Хмельницького, 2012. -536 c. 
15. Ягупов В. В. Теорія і методика військового навчання : монографія / Василь Васильович Ягупов. - К : Тандем, 2000. - 380 с.

\section{REFERENCES}

1. Avtushenko O. S. Systema pidhotovky orhanizatoriv vykhovnoi roboty $\mathrm{z}$ viiskovosluzhbovtsiamy v umovakh universytetskoi osvity: Avtoref. dys... kand. ped. nauk: 13.00.04 / O. S. Avtushenko; In-t vyshch. osvity APN Ukrainy. - K., 2003. - 20 s.

2. Baranivskyi V. F. Profesiina kompetentnist fakhivtsiv $\mathrm{z}$ vykhovnoi ta sotsialnopsykholohichnoi roboty dlia Zbroinykh Syl Ukrainy / V. F. Baranivskyi // Visnyk Natsionalnoho universytetu oborony Ukrainy. - 2012. - Vyp. 5 (30). - S. 5-10.

3. Boiko O. V. Formuvannia hotovnosti do upravlinskoi diialnosti u maibutnikh mahistriv viiskovo-sotsialnoho upravlinnia: dys. ... kand. ped. nauk: 13.00.04 / Boiko Oleh Volodymyrovych. K., 2005. $-476 \mathrm{~s}$.

4. Vitchenko A. O. Suchasni pidkhody do tekhnolohizatsii vyshchoi osvity / A. O. Vitchenko // Zbirnyk naukovykh prats: Viiskova osvita - Vyp. 1 (27). - 2013. - S. 48-58.

5. Zelnytskyi A. M. Novi pidkhody do pidhotovky ofitserskykh kadriv - fakhivtsiv vykhovnoi roboty - yak faktor zapobihannia konfliktiv u viiskovomu seredo $\neg$ vyshchi / A. M. Zelnytskyi // Konflikty v suspilstvi : diahnostyka i profilaktyka : tezy Tretoi Mizhnarodnoi naukovo-praktychnoi konferentsii. - Kyiv - Chernivtsi, 1995. - S. 3-8.

6. Ishchenko D. V. Osnovy viiskovoi pedahohiky / D. V. Ishchenko, A. F. Filipov. Khmelnytskyi : Vyd-vo Natsionalnoi akademii PVU, 2002. - 106 s.

7. Koverialh A. A. Metodoyssledovanyia v professyonalnoi pedahohyke / Koverialh A. A. Tallyn: Valhus, 1980. - $336 \mathrm{~s}$.

8. Koziar M. M. Teoretychni ta metodychni zasady profesiinoi pidhotovky osobovoho skladu pidrozdiliv z nadzvychainykh sytuatsii : avtoref. dys. na zdobuttia nauk. stupenia doktora ped. nauk: 13.00.04 "Teoriia ta metodyka profesiinoi osvity" / M. M. Koziar. - K., 2005. - 37 s.

9. Lytvynovskyi Ye. Yu. Formuvannia v ofitseriv struktury vykhovnoi roboty Zbroinykh Syl Ukrainy vmin proektuvannia vykhovnoho protsesu :dys. ... kand. ped. nauk : 13.00.04 / Lytvynovskyi Yevhenii Yuriiovych. - K, 2003. - 208 s.

10. Lihotskyi A. O. Teoretychni osnovy proektuvannia suchasnykh osvitnikh system / Anatolii Oleksiiovych Lihotskyi. - K. : Tekhnika, 1997. - 210 s.

11. Matsevko T. M. Upravlinska kompetentnist ofitseriv viiskovo-sotsialnoho upravlinnia / T. M. Matsevko Visnyk Natsionalnoho universytetu oborony Ukrainy. - 2015. - Vyp. 1(44). - S. 148153.

12. Neshchadym M. I. Viiskova osvita Ukrainy: istoriia, teoriia, metodolohiia, praktyka : monohrafiia / Mykola Ivanovych Neshchadym. - K. : Vydavnycho-polihrafichnyi tsentr "Kyivskyi universytet”, 2003. - $852 \mathrm{~s}$.

13. Stasiuk V. V. Osoblyvosti pidhotovky maibutnikh mahistriv viiskovo-sotsialnoho upravlinnia do vymoh Bolonskoho protsesu / V. V. Stasiuk, L. V. Oliinyk // Zbirnyk naukovykh prats : viiskova osvita - Vyp. 2 (28). - 2013. - S. 155-164.

14. Torichnyi O. V. Teoriia i praktyka formuvannia viiskovo-spetsialnoi kompetentnosti maibutnikh ofitseriv-prykordonnykiv u protsesi navchannia : monoh $\neg$ rafiia / O. V. Torichnyi. Khmelnytskyi : Vyd-vo Nats. akademii Derzh. prykordon. sluzhby Ukrainy im. B. Khmelnytskoho, 2012. $-536 \mathrm{~s}$.

15. Yahupov V. V. Teoriia i metodyka viiskovoho navchannia : monohrafiia / Vasyl Vasylovych Yahupov. - K : Tandem, 2000. - 380 s.

PEЗЮME

Леонид Олейник,

кандидат педагогических наук, старший научный сотрудник

Национальный університет обороны Украины имени Ивана Черняховского 


\section{Теоретико-методические основы обучения военно-специальных дисциплин магистров военно-социальногоуправления: экспериментальноеисследование}

В статье рассмотрены этапь организации и проведения педагогического эксперимента и результать развития военно-специальной компетентностимагистров военно-сочиального управления на основе использования универсальной структурно-функииональной технологии подачи содержания обучениявоенно-специальных дисииплин. Рассмотрены экспериментальное исследование и раскрыто путь констатирующего и формирующегоэксперимента. Доказано достоверность полученных результатов с помощьюметодовматематической статистики.

Ключевые слова: обучения; военно-специальные дисциплины; магистры военносоциального управления; методическая система; технология; военно-специальная компетентность.

\section{SUMMARY}

Leonid Oliynyk, candidate of pedagogical sciences, senior research scientist

National University of Defense of Ukraine named after Ivan Chernyahovskyi

\section{Theoretical and methodological fundamentals of teaching military-special disciplines masters of military and social management: an experimental research}

Introduction. Experimental research was reviewed and way of a scertaining and generating experiment was exposed concerning introducing technique of development of military and special competence of master sofmilitary and social management based onthe grounds of the content presentation in the process of teaching military and special disciplines.

Purpose. The a imof generating experiment was toexamine effective nessof the teaching military special disciplinest echniqueof masters of military and social management.

Methods. Authenticity of the got results is well-proven by means of methods of mathematical statistics.

Results. The article presents tages of organizing and conducting a pedagogical experiment and the resultsof development of military and special competence of mastersof military and social management base don the ground sofve rsatilestructural and functional techniqueof a content presentation in the process of teaching military and special disciplines.

Aiming to very fying maturitylevel of military and special competen ceofmastersof military and social management, we haved evelopedan experimental research program. In 2016-2019 ascert aining and generating experiments were conducted in the National Defence University of Ukrainen amed after Ivan Cherniakhovskyi, the National Academy of the National Guardof Ukraine, the National Academy of the State Border Guard Service of Ukrainen amed after Bohdan Khmelnytskyi. Ascer taining experiment in cluded the following stages:-determinati on of accuracy; - determination of the currentstate of the teaching military and special disciplines of masters of military and social management; - development of researchhypo thesis.

In the control groupeducation of the future master sof military and socialmanage ment was conducted under traditional technique of teaching military and special disciplines whilein the experimental groupanin novation techniqueof the content presentationin the processof teaching military and special disciplines was applied.

There sultsofex perimental research of special military competence development in the process of teaching military and special disciplines for student of ficersin the higher military educational in stitutions were summarized; a level of maturity of special military competence of masters of military- 
social management was analysed. There sults of generating experiment in the control and experimental groups in dicated advantages of military and special competencete chnique effectiveness of the student off icersin the experimental group.

Originalit. Results of the experimental researchindicate that in troduction of the applied techniqueduring educational processin the higher military educational in stitutions improve smaturity of military and special competence of masters of military and social management.

Conclusion Experimental study confirmsourhypothesisthat effectiveness of professionalactivity of masters of military and socialmanagementis higherif directive military and special competence development basedon competent approach and introduction of the applied techniquein to the educational processin the higher military educational in stitutionstakeplace.

Key words: studies; military-special disciplines; master military-social management; methodologicalsystem; technology; military-specialcompetence. 